Sketches of Early Texas

and Louisiana 
THIS PAGE INTENTIONALLY LEFT BLANK 
THIS PAGE INTENTIONALLY LEFT BLANK 


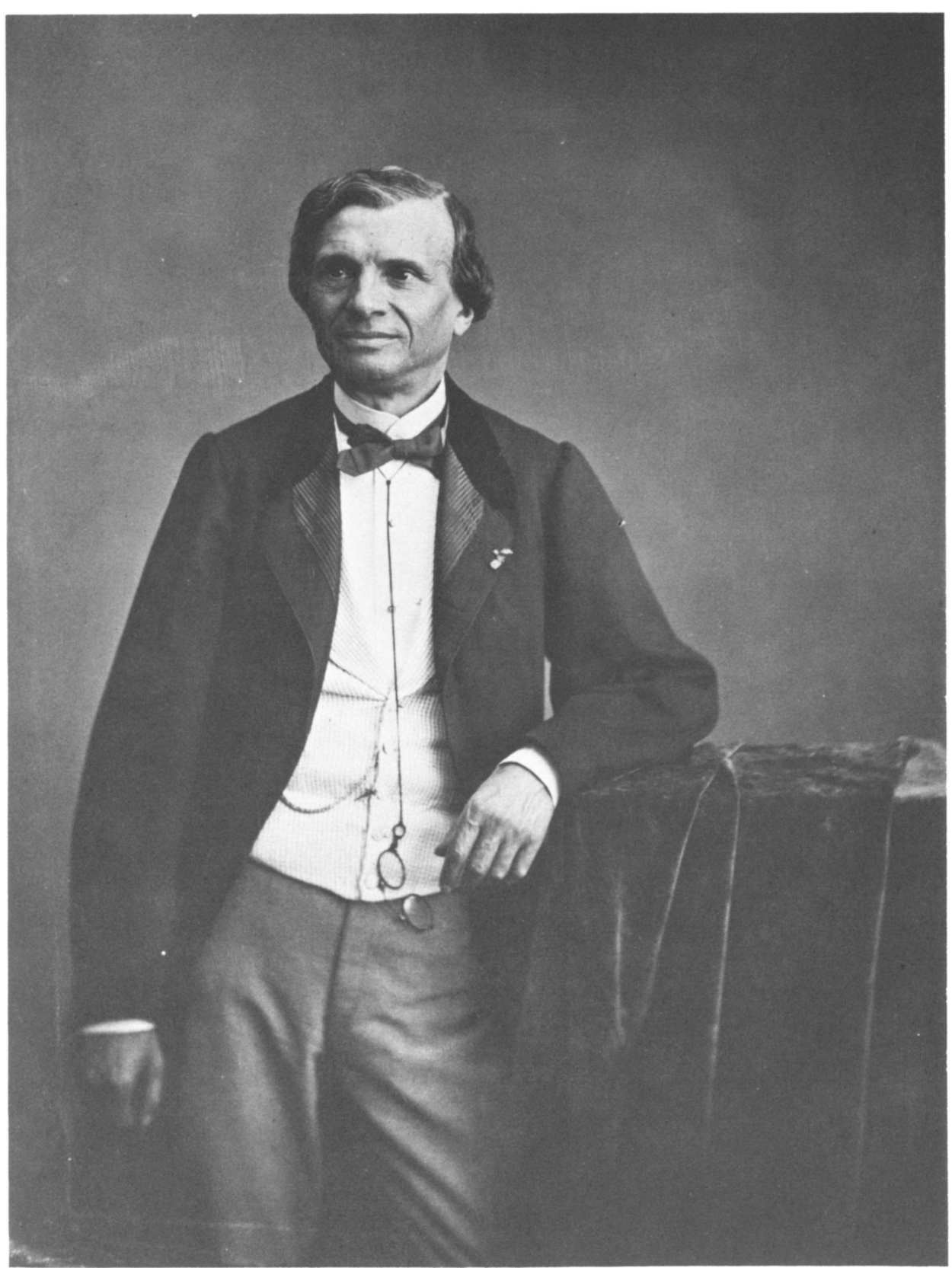

COURTESY THE ARCHIVES PHOTOGRAPHIQUES, PARIS. Photograph of Frédéric Gaillardet in middle life. 


\section{FRÉDÉRIC GAILLARDET}

\section{Sketches of Early}

\section{Texas and Louisiana}

Translated with an Introduction and Notes by JAMES L. SHEPHERD, III

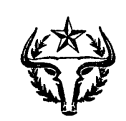

UNIVERSITY OF TEXAS PRESS, AUSTIN \& LONDON 
Library of Congress Catalog Card No. 66-27357

Copyright (C) 1966 by James L. Shepherd, III

All Rights Reserved

Printed by the University of Texas Printing Division, Austin

Bound by Universal Bookbindery, Inc., San Antonio

ISBN 978-0-292-75820-9 (e-book)

ISBN 978-0-292-75821-6 (individual e-book) 
FOR MARGUERITE CAMBIAS, a child of Texas and Louisiana, from ber Uncle Jimmie 
THIS PAGE INTENTIONALLY LEFT BLANK 